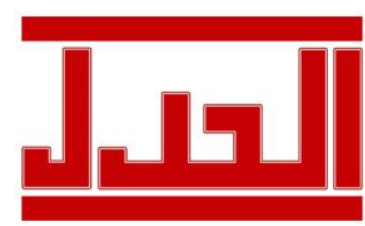

ISSN: $1979-4940$

E-ISSN: 2477-0124
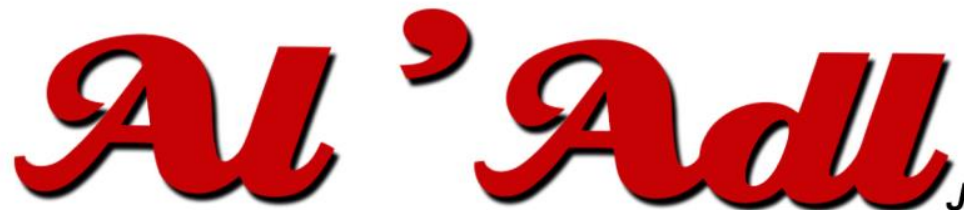

Jurnal Hukum

Editorial Office: Faculty of Law, Islamic University Of Kalimantan,

Jalan Adhyaksa No. 2 Kayutangi Banjarmasin, Kalimantan Selatan, Indonesia (70123)

Email: al_adl@uniska-bjm.ac.id

Web: http://ojs.uniska-bjm.ac.id

\title{
PERTANGGUNGJAWABAN HUKUM PADA PENGELOLAAN DANA HAJI UNTUK INVESTASI INFRASTURKTUR
}

\author{
Aulia Muthiah \\ Fakultas Hukum Universitas Achmad Yani Banjarmasin \\ Jl. Jend. Achmad Yani Km.5,5, Pemurus Baru, Kecamatan Banjarmasin Selatan, Kelurahan \\ Pemurus Baru, Kota Banjarmasin, Kalimantan Selatan 70249 \\ Email: auliamuthiah@gmail.com
}

$\begin{array}{ll}\text { Submitted } & : \text { 2 Desember 2021 } \\ \text { Revised } & : \text { 11 Desember 2021 } \\ \text { Accepted } & : \text { 17 Desember 2021 } \\ \text { Published } & : \text { 18 Januari 2022 }\end{array}$

Jurnal Al Adl by Universitas Islam Kalimantan Muhammad Arsyad albanjari is licensed under a Creative Commons Attribution 4.0 International License. (CC-BY)

\begin{abstract}
That Indonesian people's hajj funds will be used for infrastructure investment has become a quite complicated debate. The majority of Indonesians disagree on this policy as they are worried that the hajj funds having been saved will vanish if this investing activity fails. In terms of managing Hajj funds for infrastructure investment, it definitely requires a comprehensive understanding in order for us to be wiser in responding to the ideas conveyed by the government. This research discusses the juridical basis and the form of government's responsibility as the one using public funds for investment purposes. The research method used is normative juridical with a legislative approach focusing on the use of legal norms related to statutory regulations regarding Hajj and investment. The results reveal that the use of Hajj funds for infrastructure investment does not go against applicable legal provisions provided that the investment made is based on sharia principles mandated by the Hajj Financial Management Act. If the investment is profitable, the revenue distribution is used to improve the quality of Hajj services and also reduce the cost of the Hajj. However, if the investment is unprofitable, BPKH must also be responsible - not only joint and several liability, but also personal responsibility.

Keywords: Hajj Funds, Infrastructure Investment.
\end{abstract}

Abstrak
Perdebatan tentang dana haji masyarakat indonesia yang akan digunakan untuk investasi infrastruktur cukup
rumit. Mayoritas masyarakat indonesia tidak menyetujui kebijakan ini sebab mereka khawatir dana haji yang
selama ini mereka kumpulkan akan hilang jika kegiatan investasi ini gagal. Pada konteks pengelolaan dana haji
untuk investasi infrastrktur tentunya memerlukan pemahaman yang komprehensif agar kita bisa lebih bijak
menyikapi gagasan yang dilontarkan oleh pemerintah. Pada penelitian akan dibahas tentang landasan yuridisnya
dan bentuk pertanggung jawaban pemerintah selaku pihak yang menggunakan dana masyarakat untuk
kepentingan investasi. Metode penelitian yang digunakan adalah yuridis normatif dengan pendekatan perundang-
undangan yang menitik beratkan kepada penggunaan norma-norma hukum terkait dengan peraturan perundang-
undangan tentang haji dan investasi. Hasil penelitian menyatakan bahwa penggunaan dana haji untuk investasi
inftastruktur tidak bertentangan dengan ketentuan hukum yang berlaku, selama investasi ini dilakukan dengan
berstandar prinsip syariah yang diamanatkan oleh UU Pengelolaan keuangan haji. Jika investasi menguntungkan
maka pembagian hasilnya benar-benar untuk meningkatkan kualitas pelayanan haji dan juga menekan biaya haji


tersebut. Namun jika investasi merugi BPKH juga harus bertanggungjawab tidak hanya tanggung jawab renteng namun harus ditambah dengan tanggung jawab secara privat.

Kata Kunci : Dana Haji; Investasi Infrastruktur.

\section{PENDAHULUAN}

Ibadah haji merupakan kegiatan rukun iman. Terhukumkan wajib untuk umat Islam yang mempunyai kemampuan fisik dan finansial. Umat Islam di Indonesia sangat antusias dengan kewajiban berhaji, sehingga untuk melaksanakan ibadah haji jamaah Indonesia harus melalui tahapan waiting list. Untuk mendapatkan porsi dari waiting list calon jamaah haji harus menyetorkan dana sebanyak 25 juta Rupiah. Dana ini terus menumpuk sehingga pada November 2013 dana setoran awal haji mencapai angka 58 Triliun dan pada tahun 2018 penambahan angka mencapai 3,1 triliun Rupiah. ${ }^{1}$ Tumpukan dan haji yang setiap tahunnya terus meninggat menjadikan sebuah ide yang dilontarkan oleh pemerintah agar dana tersebut dapat digunakan untuk pembangunan infrastruktur.

Hiruk pikuk permasalahan dana haji ini membuat sebuah video tahun 2017 berisi tentang Wakil Presiden Ma'ruf Amin yang berbicara tentang investasi dana haji untuk infrastruktur kembali viral dan lagi-lagi masyarakat kembali menjadi resah. Keresahan ini juga dipicu dengan pembatalan keberangkatan haji pada tahun 2021 ini.

Adapun isi video yang kembali viral itu ketika $\mathrm{KH}$ Ma'ruf Amin berbicara selaku ketua MUI 2015-2020 menjelaskan tentang standar normatif berupa prinsip syariah yang harus diterapkan dalam investasi penggunaan dana haji. Berdasarkan dalam Undang-undang Nomor 34 Tahun 2014 tentang Pengelolaan Keuangan Haji. Pada undang-undang ini menyebutkan bahwa pengelolaan dana haji harus berasaskan prinsip syariah. Prinsip syariah yang dimaksud harus merujuk pada fatwa MUI. Beliau juga menegaskan bahwa dana haji yang dikelola oleh Badan Pengelola Keuangan Haji (BPKH) boleh diinvestasikan sesuai dengan skema investasi syariah. Jika dana haji hendak diinvestasikan maka dana tersebut hanya boleh digunakan untuk proyek-proyek yang aman. ${ }^{2}$

Pada video ini beliau menerangkan kebolehan menginvestasikan dana haji dengan catatan sesuai dengan kaidah-kaidah investasi syariah. Namun sebaliknya Fahri Hamzah mengecam rencana pemerintah yang hendak menginvestasikan dana haji untuk pembangunan

${ }^{1}$ Republika, https://www.republika.co.id/berita/koran/opini-koran/14/06/20/n7gb8840-pengelolaan-danahaji (diakses pada 31 Desember 2021 pukul 06.30 WITA).

${ }^{2}$ Liputan6.com, https://liputan6.com “Jubir Wapres Sampaikan Klarifikasi Video Ma'ruf Amin tentang Investasi Dana Haji” (diakses pada 09 Juni 2021 pukul 10.00 WITA). 
infrastruktur. Beliau menilai rencana tersebut berpotensi melanggar Undang-Undang Nomor 34 Tahun 2014 tentang Pengelolaan Dana Haji. Beliau juga berpendapat akan lebih baik jika dana haji digunakan untuk perbaikan pelayanan haji yang masih banyak masalah. ${ }^{3}$

Sejak awal masa jabatan Presiden Joko Widodo, masalah pembangunan infrastruktur memang menjadi fokus utama beliau. Sehingga ketika beliau melantik Dewan Pengawas dan Anggota BPKH dalam pidato pelantikan beliau juga menyampaikan gagasan untuk menjadikan dana haji masyarakat indonesia sebagai dana investasi pembangunan infrastruktur.

Beliau berpandangan bahwa jika dana haji yang mengendap bertahun-tahun bisa dijadikan dana investasi infrastruktur yang mana keuntungannya dapat dipakai untuk menyubsidi biaya haji agar lebih terjangkau oleh masyarakat. Investasi itu harus dijalankan dengan prinsip kehati-hatian dan selalu mengikuti peraturan perundang-undangan yang berlaku. $^{4}$

BPKH terbentuk berdasarkan amanat dari Undang-Undang Nomor 34 Tahun 2014 tentang Pengelolaan Keuangan Haji. BPKH bersifat mandiri dan bertanggung jawab sepenuhnya kepada Presiden melalui mentri Agama. Pengelolaan dana haji dalam bentuk investasi diharapkan keuntungan yang didapat dapat digunakan untuk meningkatkan mutu pelayanan penyelenggaraan haji. Penggunaan dana haji menggunakan perjanjian kerjasama antara Ditjen Penyelenggaraan Haji dan Umrah Kementrian Agama dan Bank sebagai penerima setoran biaya haji dengan menggunakan akad wakalah. Posisi jamaah disini sebagai muwakil yang memberikan kuasa kepada Kementrian Agama selaku wakilnya. ${ }^{5}$

Pada dasarnya investasi merupakan bagian dari Fiqih Muamalah, maka berlakulah sebuah prinsip "hukum asal dalam semua bentuk muamalah adalah boleh kecuali ada suatu dalil yang mengharamkannya."6 Namun demikian investasi harus menurut pada koridor prinsip syariah yaitu mengandung penipuan dan kebohongan atau mengandung unsur-unsur kegiatan yang dilarang syariat Islam.

\footnotetext{
Beritagar, https://beritagar.id/artikel/berita/pro-konta-dana-haji-untuk-pembiayaan-infrastruktur, (diakses pada 09 Juni 2021 pukul 10.25 WITA).

4 Nasional Kompas, https://nasional.kompas.com/red2017/07/30/13415151/jokowi-investasi-dana-hajiharus-mengentungkan (diakses pada 09 Juni 2021 pukul 11.45 WITA).

5 Maria Ulfa Kn, (2019), "Pengelolaan Dana Haji Oleh Badan Pengelola Keuangam Haji Tanpa Pengawasan Otoritas Jasa Keuangan (Perspektif Hukum Islam”), Tesis Universitas Islam Negeri Sunan Kalijaga, Magister Ilmu Syariah, hlm. 5.

${ }^{6}$ Elif Pardiansyah, (2017), "Infestasi dalam Perspektif Ekonomi Islam: Pendekatan Teritis dan Empiris", Economica: Jurnal Ekonomi Islam, Volume 8 Nomor 2 Tahun 2017, hlm. 339.
} 
Pemanfaatan dana haji untuk investasi infrastruktur sudah dilakukan oleh Negara Malaysia. Tabungan haji para jamaahnya dikelola secara menyeluruh untuk pembangunan diberbagai sektor. Kehadiran tabungan jamaah haji di pasar domestik dan internasional telah terbukti progresif di beberapa sektor investasi seperti keuangan islam, pengembangan properti, kontruksi, teknologi informasi, minyak dan gas, perhotelan dan perkebunan. Tabungan haji di Malaysia bisa menjadi simbol dan ikon untuk komunitas Muslim di dunia karena pengelolaan layanan yang sangan baik berdasarkan ajaran Islam. ${ }^{7}$ Tentunya Indonesia dapat menerapkan kebijakan ini dengan terlebih dahulu mempelajari seluk beluk investasi dana haji yang ada di Malaysia.

Gagasan pemerintah tentang penggunaan dana haji untuk pembangunan infrastrktur menuai pro dan kontra dari berbagai kalangan, baik itu dari politisi, akademisi dan masyarakat. Meskipun contoh riil dari Negara Malaysia sudah ada, namun rasa pesimis untuk menerapkan kebijakan ini masih ada pada benak masyarakat. Perbedaan pendapat ini menjadi salah satu alasan penulis untuk mengkaji permasalahan ini lebih dalam lagi. Pada konteks pengelolaan dana haji untuk investasi infrastrktur tentunya memerlukan pemahaman yang komprehensif agar kita bisa lebih bijak menyikapi gagasan yang dilontarkan oleh pemerintah. Pada penelitian akan dibahas tentang landasan yuridisnya dan bentuk pertanggung jawaban pemerintah selaku pihak yang menggunakan dana masyarakat untuk kepentingan investasi.

\section{RUMUSAN MASALAH}

Berdasarkan paparan pada latar belakang masalah di atas, selanjutnya rumusan masalah pada penelitian ini adalah:

1. Bagaimanakah prinsip syariah sebagai pedoman dalam penggunaan dana haji untuk investasi infrastruktur?

2. Bagaimanakah bentuk tanggung jawab BPKH terkait penggunaan dana haji untuk investasi pembangunan infrasturktur?

${ }^{7}$ Habibah Yahya, Mohd Suhaini Abdul Majid, Aida Zuraina Mir Ahmad Talaat, Mohd Zaid Zulkifli, dan Nor Shaiza Mir Ahmad Talaat, (2016), "Tabungan Haji Malaysia as a World Role Model of Islamic Management Instituions", Internasional Journal of Bussines adn Management Invention, Volume 5 Nomor 11 Tahun 2016, hlm. 48 . 


\section{METODE PENELITIAN}

Penelitian ini menggunakan pendekatan Yuridis Normatif dengan pendekatan perundang-undangan yang menitik beratkan kepada penggunaan norma-norma hukum yang sudah menjadi hukum positif. ${ }^{8}$ Peraturan-peraturan terkait dengan pembahasan adalah Undang-Undang Nomor 13 Tahun 2008 tentang Penyelenggaraan Ibadah Haji, UU nomor 34 Tahun 2014 Tahun 2014 tentang Pengelolaan Keuangan Haji, Peraturan Pemerintah Nomor 5 Tahun 2018 tentang Pelaksanaan Undang-Undang Nomor 34 Tahun 2014 tentang Pengelolaan Keuangan Haji, dan Kompilasi Hukum Ekonomi Syariah.

Penelitian hukum normatif dengan pendekatan studi kasus metode analisis yang banyak digunakan adalah content analysis yaitu menguraikan materi peristiwa hukum atau produk hukum secara rinci guna memudahkan interpretasi dalam pembahasan. Terdapat dua content analysis yaitu: (1) tinjauan yuridis yang merupakan bentuk analisis dari berbagai aspek dan mengungkap segi positif dan negatif suatu produk hukum dengan menitik beratkan pada penggunaan data sekunder. (2) analisis yuridis merupakan bentuk analisis berbagai aspek dan mengungkap segi positif dan negatif suatu produk hukum dengan menitikberatkan pada penggunaan data primer. $^{9}$

Objek dari penelitian ini adalah analisis yuridis penggunaan dana haji untuk investasi infrastruktur yang mana fokus analisisnya tertuju pada Undang-Undang Nomor 34 Tahun 2014 tentang Pengelolaan Keuangan Haji dan peraturan pelaksananya. Selanjutnya pembahasan dilanjutkan dengan bentuk tanggung jawab Badan Pengelola Keuangan Haji sebagai pengelolala keuangan haji. Tanggung jawab hukum sangat urgen untuk dibahas mengingat dana haji adalah dana umat Islam yang sengaja menitipkan kepada pemerintah agar mendapatkan nomor porsi pemberangkatan haji. Kegiatan investasi adalah kegiatan untung dan rugi maka dari itu, dana milik masyarakat harus mendapatkan perlindungan dalam bentuk pertanggungjawaban dari pemerintah.

\footnotetext{
${ }^{8}$ Abdul Kadir Muhammad, (2004), Hukum dan Penelitian, Bandung: PT. Citra Adtya Bakti, hlm. 82.

${ }^{9}$ Ibid., hlm. 42.
} 


\section{PEMBAHASAN}

\section{Prinsip Syariah Sebagai Pedoman dalam Penggunaan Dana Haji Untuk Investasi Infrastruktur}

Ibadah haji merupakan ibadah wajib yang masuk dalam rukun Islam. Kewajiban ini dibebankan kepada mereka yang mempunyai kemampun fisik dan finansial. Penyelenggaraan ibadah haji harus dilaksanakan di kota Makkah, hal ini yang menyebabkan ibadah haji tergolong sebagai ibadah yang cukup mahal. Meskipun harga yang ditentukan untuk penyelenggaraan ibadah haji cukup mahal, tetapi antusias masyarakat cukup banyak. Alhasil daftar tunggu untuk melaksanakan ibadah haji semakin tahun semakin panjang.

Akumulasi jumlah dana jamaah haji mempunyai potensi untuk terus meningkat. Sehingga kemanfaatan dana jamaah haji tidak hanya untuk biaya pemberangkatan, tetapi juga dapat digunakan untuk investasi pada sektor-sektor lain yang bertujuan untuk meningkatkan kualitas pelayanan penyelenggaraan ibadah haji.

Saat ini juga bergulir isu penggunaan dana haji untuk kepentingan investasi infrastruktur. Isu ini adalah isi pidato presiden Joko Widodo pada Tahun 2017 ketika beliau melantik Dewan Pengawas dan Anggota Badan Pengelola Keuangan Haji (BPKH) di Istana Negara.

Adapun Undang-undang yang secara khusus mengatur tentang pengelolaan dana haji di atur di dalam Undang-Undang Nomor 34 Tahun 2014 tentang Pengelolaan Keuangan Haji (UU Pengelolaan Keuangan Haji). Undang-undang ini menjelaskan pengertian dari dana haji pada Pasal 1 angka (2) yaitu: "Dana haji adalah dana setoran biaya penyelenggaraan ibadah haji, dana efisiensi penyelenggaraan haji, dana abadi umat, serta nilai manfaat yang dikuasai oleh negara dalam rangka penyelenggaraan ibadah haji dan pelaksanaan program kegiatan untuk kemaslahatan umat Islam."

Secara khusus Pasal 5 Undang-Undang ini menyebutkan ada 5 macam bentuk penerimaan keuangan haji, yaitu:

1. Setoran BPIH dan/atau BPIH khusus

2. Nilai manfaat Keuangan haji

3. Dana efisiensi penyelenggaraan ibadah haji

4. DAU dan/atau

5. Sumber lain yang sah dan tidak mengikat.

UU Pengelolaan Keuangan Haji dibuat dengan tujuan agar menjamin terwujudnya pengelolaan keuangan haji yang ideal. UU Pengelolaan Keuangan Haji ini mengatur tentang 
keuangan haji yang meliputi, penerimaan, pengeluaran, dan kekayaan. Sedangkan dalam pengelolaannya dilakukan dalam bentuk investasi yang mana nilai manfaatnya digunakan untuk peningkatan kualitas penyelenggaraan ibadah haji, rasionalitas, efisiensi Biaya Penyelenggaraan Ibadah Haji (BPIH) dan kemaslahatan umat. ${ }^{10}$

Jumlah dan haji yang masuk setiap tahunnya meningkat, pengelolaan dan haji ini dirasa belum maksimal karena penggunaannya sebatas investasi dalam bentuk produk perbankan, surat berharga, emas, investasi langsung dan investasi lainnya. ${ }^{11}$ Pada praktiknya saat ini penggunaan dana haji dikelola oleh perbankan syariah dan investasinya hanya sebatas produk-produk perbankan syariah saja.

Berdasarkan jumlah dana haji yang semakin menumpuk dan pemanfaatannya yang kurang maksimal, sehingga hal ini yang menjadikan alasan dasar oleh Presiden untuk mewacanakannya menjadi dana investasi pembangunan infrastruktur. Mengingat dana inverstasi infarstruktur keuntungannya bisa mencapai $12 \%$ (dua belas persen) menurut Darwis Nasution. ${ }^{12}$ Kalimat yang tercantum di dalam undang-undang berupa "investasi langsung dan investasi lainnya" maka kalimat ini memberikan isyarat bahwa investasi infrastruktur sangat mungkin untuk dilakukan.

Walaupun keuntungan yang ditawarkan cukup banyak, namun ketika dana haji harus diinvestasikan sudah seharusnya kembali kepada UU Pengelolaan Keuangan Haji harus dilakukan dengan prinsip syariah, prinsip kehati-hatian, prinsip keamanan dan prinsip nilai manfaat. Selanjunya pengelolaan dana haji di lakukan oleh BPKH yang mana tugas pokoknya berdasarkan Pasal 22 UU Pengelolaan Keuangan Haji yaitu: "BPKH bertugas mengelola keuangan haji yang meliputi penerimaan, pengembangan, pengeluaran dan pertanggungjawaban keuangan haji."

Dalam hal mengelola keuangan haji BPKH berwenang sebagaimana Pasal 24 yaitu:

a. Menempatkan dan menginvestasikan keuangan haji sesuai dengan prinsip syariah, kehatihatian, keamanan, dan nilai manfaat; dan

b. melakukan kerja sama dengan lembaga lain dalam rangka pengelolaan keuangan haji.

Kata Investasi secara etimologi dari bahasa latin di sebut dengan kata "Investatie" yang berarti memakai, yang di dalam bahasa inggris yang di sebut dengan kata "Investment",

\footnotetext{
${ }^{10}$ Ahmad Fathurrozi, (2019), “Analisis Maslahah Mursalah Terhadap Pengelolaan Dana Haji Oleh BPKH Untuk Investasi Pembangunan Infrastrktur”, Skripsi Universitas Islam Negeri Sunan Ampel Fakultas Syariah, Surabaya, hlm. 45.

${ }^{11}$ Lihat Pasal 48 Undang-Undang Nomor 34 Tahun 2014 tentang Pengelolaan Keuangan Haji.

12 Sulasi Rongiyati, (2017), "Perspektif Yuridis Pengelolaan Dana Haji Untuk Investasi Infrastrktur", Majalah Info Singkat Hukum, Volume IX, Nomor 15/I/Puslit/Agustus/2017, hlm. 3.
} 
yang berarti menanam. Dalam istilah pasar modal dan keuangan kata investasi di definisikan sebagai pemberian label identitas atau nama uang atau modal dalam suatu perusahaan atau proyek dengan tujuan untuk memperoleh keuntungan. ${ }^{13}$

Investasi juga merupakan salah satu hal yang penting dalam era modern seperti sekarang ini. Indonesia, sebagai negara berkembang terus melakukan berbagai pembangunan terutama dibidang ekonomi. Investasi adalah sebuah komitmen atas sejumlah dana atau sumber dana lainnya yang dilakukan saat ini, dengan tujuan memperoleh sejumlah keuntungan pada masa akan datang. ${ }^{14}$ Pendapat lain terkait dengan definisi investasi adalah sebuah proses investasi menunjukkan bagaimana pemodal seharusnya melakukan investasi dalam sekuritas, yaitu sekuritas yang akan dipilih, seberapa banyak investasi tersebut dan kapan investasi tersebut akan dilakukan. ${ }^{15}$

Jadi yang dimaksud dengan investasi penanaman sejumlah uang pada suatu proyek atau perusahaan yang tujuannya adalah untuk mendapatkan keuntungan. Dalam hal pembahasan ini adalah penggunaan dana haji masyarakat yang sudah disetorkan namun harus mengendap terlebih dahulu sebab panjangnya antrian keberangkatan. Dana inilah yang digagas untuk dijadikan sebagai modal investasi infrastruktur, keuntungan dari proyek akan digunakan untuk kemaslahatan pelayanan haji atau menekan biaya haji agar lebih terjangkau.

Gagasan penggunaan dana haji ini sebenarnya bagus dan menguntungkan, namun ketika investasi ini harus tunduk pada UU Pengelolaan Keuangan Haji, maka secara otomatis juga harus mengikuti peraturan pelaksananya yaitu Peraturan Pemerintah Nomor 8 Tahun 2018 tentang Pelaksana Undang-Undang Nomor 34 Tahun 2014. Peraturan ini menyebutkan pada Pasal 30 Ayat 3 yaitu: “investasi langsung sebagaimana dimaksud pada Ayat 1 paling banyak 20\% (dua puluh persen) dari total penempatan dan/atau investasi keuangan haji." Sedangkan pada Pasal 31 ayat 1 menyebutkan bahwa: "investasi lainnya sebagaimana dimaksud dalam Pasal26 ayat 2 ditetapkan oleh BPKH." Selanjutnya pada ayat 2 menegaskan "investasi lainnya sebagaimana dimaksud pada ayat 1 paling banyak 10\% (sepuluh persen) dari total penempatan dan/atau investasi keuangan haji. "16

13 Rony Wahyu Hidayat, (2014), "Peluang Dan Tantangan Investasi Properti Di Indonesia," Jurnal Akuntansi AKUNESA 2, Nomor 2, hlm. 15.

hlm. 7.
${ }^{15}$ Suad Hasan, (2005), Dasar-Dasar Teori Potofolio dan Analisis Sekuritas, Yogyakarta: UPP AMP YKPN, hlm. 48.

${ }^{16}$ Lihat Peraturan Pemerintah Nomor 5 Tahun 2018 tentang Pelaksanaan Undang-Undang Nomor 34 Tahun 2014 tentang Pengelolaan Keuangan Haji. 
Baik itu UU Pengelolaan Keuangan Haji dan Peraturan Pelaksananya dalam hal ini sepekat memberikan kebolehan untuk menginvestasikan dana haji sebagai dana investasi pembangunan infarstruktur. Akan tetapi dalam hal pengelolaannya BPKH harus berkomitmen dan bertanggung jawab hanya memberikan dana 30\% (tiga puluh persen) saja dan selalu mengawasi investasi ini dilakukan dengan prinsip syariah dan memperimbangkan aspek keamanan, kehati-hatian dan kemanfaatannya.

Investasi dana haji merupakan ruang lingkup dari kegiatan muamalah. Hukumnya halal sebab tidak ada suatu dalil yang mengharamkannya. Aktivitas investasi dalam Islam mempunyai dua aspek yaitu:

1. Aspek non ekonomis, yaitu segala bentuk kegiatan manusia yang memiliki nilai ibadah atau amal shaleh sebagai bentuk investasi dihari penghisaban nanti.

2. Aspek ekonomis, ialah segala bentuk pengorbanan dana atau material dalam jumlah tertentu (pasti) baik pada waktu sekarang guna mendapatkan keuntungan di masa yang mendatang. ${ }^{17}$

Standar prinsip syariah yang dikehendaki oleh undang-undang adalah semua dan setiap pengelolaan keuangan haji berdasarkan prinsip Islam yang kafah atau menyeluruh. Investasi yang sesuai dengan prinsip syariah adalah investasi yang halal dan tidak mengandung unsur riba, maysir dan gharar, juga patuh pada aturan-aturan yang ditetapkan kaidah-kaidah fiqih yang tertuang di dalam fatwa-fatwa ulama. ${ }^{18}$

Investasi berstandar prinsip syariah bertujuan untuk mendapatkan keuntungan finansial dan keuntungan sosial. Investasi merupakan aktifitas muamalah yang mana prinsipnya segala sesuatu boleh dilakukan selama tidak ada dalil yang melarangnya. Jadi apa saja yang diinvestasikan dan apa saja jenis usahanya tidak ada larangan selama tidak melanggar asas umum yaitu riba, maysir dan gharar.

Secara umum praktik muamalah pada kajian hukum ekonomi syariah harus bersandar pada asas-asas sebagai berikut:

1. Pada dasarnya segala bentuk muamalah adalah boleh dilakukan sebelum ada dalil yang melarangnya.

2. Muamalah dilakukan atas dasar sukarela tanpa ada unsur paksaan (al-hurriyah)

3. Muamalah dilakukan atas dasar mendatangkan manfaat dan menghindari mudharat

17 Abdur Rahman Adi Saputera dan Muhammad Yusuf Putra, (2020), “Tinjauan Hukum Islam Terhadap Problematika Investasi Haji Pada Masa Pandemi Virus Covid-19”, El Ahli: Jurnal Hukum Keluarga Islam, Volume 1 Nomor 2 Desember 2020, hlm. 12.

18 Ina Nur Inayah, (2020), "Prinsip-Prinsip Ekonomi Islam dalam Investasi Syariah", Jurnal Ilmu Akuntansi dan Bisnis Syariah, Volume II Nomor 02, Juli 2020, hlm. 95. 
4. Muamalah dilakukan atas dasar keadilan (a'dalah). ${ }^{19}$

Asas-asas tersebut diatas sebagai pedoman dasar dalam menjalankan kegiatan investasi. Kelima asas ini harus diimplementasikan pada saat dana haji dijadikan sebagai dana investasi infrastruktur. Beradasarkan ketentuan asas di atas maka investasi pembangunan infrastruktur secara umumnya boleh dilakukan sebab tidak ada dalil yang melarang untuk melakukan investasi tersebut. Di dalam perjanjian wakalahnya juga harus menjabarkan unsur kemanfaatan, meniadakan kemudharatan dan keadilan bagi para pihak. Penjabaran kedua nilai tersebut agar tidak ada unsur paksaan dalam menjalankan perjanjian kerjasama investasi.

Selanjuntnya dana haji yang akan diinvestasikan untuk pembangunan infrastruktur harus berpedoman pada prinsip syariah. Secara khusus fatwa DSN-MUI No.80/DSNMUI/III/2011 mengatur bagaimana memilih investasi yang dibolehkan oleh hukum hukum Islam dan melarang kegiatan yang bertentangan dengan prinsip syariah. Adapun aturan-aturan tersebut adalah:

1. Maisir, yaitu setiap kegiatan yang melibatkan perjudian di mana pihak yang memenangkan perjudian akan mengambil taruhannya;

2. Gharar, yaitu ketidakpastian dalam suatu akad, baik mengenai kualitas atau kuantitas objek akad maupun tentang penyerahannya;

3. Riba, tambahan yang diberikan dalam pertukaran barang-barang ribawi dan tambahan yang diberikan atas pokok utang dengan imbalan penangguhan imbalan secara mutlak;

4. Batil yaitu jual beli yang tidak sesuai dengan rukun dan akad

5. Bay'I ma'dum, yaitu melakukan jual beli atas barang yang belum dimiliki

6. Ihtikar, yaitu membeli barang yang sangat dibutuhkan masyarakat (barang pokok) pada saat harga mahal kemudian barang ditumbun sebanyak-banyaknya dan dijual pada saat harga lebih mahal lagi. ${ }^{20}$

Keenam rambu-rambu ini tidak boleh dilakukan oleh para pelaku investasi sebab keenam larangan ini bertentangan dengan hukum Islam. Jika dana haji harus diinvestasikan untuk pembangunan infrastrktur maka para pelaku harus menjauhi perbuatan-perbuatan ini.

Ketentuan tentang investasi dengan prinsip syariah ini juga dijelaskan oleh Abdul Aziz di dalam bukunya yang berjudul Manajemen investasi Syariah. ${ }^{21}$ Prinsip ini harus dipegang teguh bagi para investor yang hendak mengivestasikan dananya pada suatu perusahaan atau suatu proyek. Adapun prinsip yang dimaksud adalah:

${ }^{19}$ Ahmad Azhar Basyir, (2000), Asas-asas Hukum Muamalah, Yogyakarta: UII Press, hlm. 27.

${ }^{20}$ Fatwa DSN dikutip dari Ina Nur Inayah, (2020), "Prinsip-prinsip Ekonomi Islam dalam Investasi Syariah”, Jurnal Ilmu Akuntansi dan Bisnis Syariah, Volume II Nomor 02, Juli 2020, hlm. 96.

${ }^{21}$ Abdul Aziz, (2010), Manajemen Investasi Syariah, Bandung: Alfabeta, hlm. 27. 
1. Tidak mencari rezeki pada sektor usaha haram, baik dari segi zatnya (objeknya) maupun prosesnya (memperolah, mengolah dan mendistribusikan), serta tidak mempergunakan untuk hal-hal yang haram;

2. Tidak menzalimi dan tidak pula dizalimi;

3. Keadilan pendistribusian pendapatan;

4. Transaksi yang dilakukan atas dasar rida (an-taradin) tanpa ada paksaan;

5. Tidak ada unsur riba, maysir, (perjudian), gharar (ketidakjelasan, kemudharatan), tadlis (penipuan) dan tidak mengandung maksiat.

Berdasarkan pada uraian di atas maka dapat disimpulkan bahwa penggunaan dana haji untuk investasi pembangunan infrastruktur sangat mungkin untuk dilakukan mengingat ketentuan Pasal 48 UU Pengelolaan Keungan Haji yang menyebutkan "investasi lainnya” dan juga diperkuat dengan adanya PP Nomor 8 Tahun 2018 sebagai peraturan pelaksananya yang menyebutkan bahwa khusus investasi lainnya hanya bisa digunakan 10 persen dari dana setoran haji masyarakat.

BPKH sebagai pengelola keuangan haji yang berkomitmen mengelola dana haji umat Islam harus selalu menjaga dana umat yang diinvestasikan kepada pihak ketiga dalam koridor prinsip syariah dan keamanan dana. Tujuan Islam mengatur investasi berprinsip syariah adalah untuk menjaga dana tersebut dari perbuatan yang akan merugikan pengelolanya dan masyarakat sebagai pemilik dananya. Selain itu keuntungan investasi dalam Islam yang akan diperoleh tidak hanya sebatas keuntungan materi saja tetapi seluruh aspek finansial, kehalalan dan aspek sosial, sehingga tujuan akhir dari kegiatan bermuamalah adalah untuk mencapai ridha Allah Swt, jadi investasi ini bertujuan untuk kemaslahatan seluruh umat Islam yang mana setiap orang hakikatnya mengharapkan ridha Allah.

\section{Bentuk Tanggung Jawab BPKH Terkait Penggunaan Dana Haji Untuk Investasi Pembangunan Infrasturktur}

Proses investasi menunjukkan bagaimana pemodal seharusnya melakukan investasi dalam sekuritas, yaitu sekuritas yang akan dipilih, seberapa banyak investasi tersebut dan kapan investasi harus dilaksanakan. Dalam hal ini tentunya yang akan diinvestasikan adalah dana haji umat yang mana keuntungannya untuk kemaslahatan umat Islam. Penggunaan dana haji untuk investasi infrastruktur tidak akan terlepas dari untung ataupun rugi, sebab pembangunan infrasturktur memakan waktu cukup lama sekitar 5 sampai 10 tahun. Pada saat realisasi pembangunan yang cukup lama sangat mungkin adanya kegagalan investasi disebabkan kesalahan pekerja atau adanya hal yang tidak diduga semisal bencana alam (force 
marge). Sehingga dalam hal investasi ini perlu kajian lebih dalam mengenai apa tanggung jawab BPKH sebagai pihak yang mengelola dana haji masyarakat.

Masyarakat sebagai pemegang modal hakiki tentunya harus mendapatkan perlindungan sebab dana yang digunakan untuk investasi tersebut akan digunakan juga untuk keberangkatan haji, jika daftar tunggu telah berakhir. Jika terjadi kerugian dalam hal investasi ini siapakah yang bertanggung jawab dan apa bentuk tanggung jawab yang ditawarkan demi memberikan perlindungan terhadap hak-hak masyarakat.

Beginilah ilustrasi kemungkinan buruk dalam kegiatan investasi. Namun sebagaimana kita ketahui pemanfaatan dana haji oleh pemerintah untuk dana investasi pembangunan infrastrktur belum dilaksanakan. Akan tetapi ketika kita menelisik secara detail UU Pengelolaan Keuangan Haji tersebutlah di Pasal 48 Ayat (1) yaitu: "penempatan dan/atau investasi Keuangan Haji dapat dilakukan dalam bentuk produk perbankan, surat berharga, emas, investasi langsung dan investasi lainnya."

UU Pengelolaan Keuangan Haji memberikan isyarat dengan sebutan investasi langsung dan investasi lainnya. Akan tetapi meskipun UU telah memberikan isyarat untung dan rugi investasi tetap saja harus menjadi prioritas yang diperhatikan dengan hati-hati sebab dana yang digunakan adalah dana masyarakat.

UU Pengelolaan Keuangan Haji dan peraturan pelaksananya adalah produk hukum, yang mana ketika Undang-Undang ini sudah disahkan maka jadilah dia sebagai sandaran masyarakat dalam bertindak. Produk hukum dibuat tidak bisa terlepas dari pada tujuannya, sebagaimana pendapat dari Sudikno Mertokusumo "tujuan pokok hukum adalah menciptakan tatanan masyarakat yang tertib, menciptakan ketertiban dan keseimbangan." 22 Satjipto Raharjo berpendapat bahwa "tujuan hukum adalah menciptakan tata tertib di dalam masyarakat." 23 Adapun Purnadi Purbacaraka dan Soerjono Soekanto menjelaskan bahwa "tujuan hukum adalah kedamaian hidup antarpribadi yang meliputi ketertiban ekstern antar pribadi dan ketenangan intern antar pribadi." 24 Jadi sesungguhnya hukum sangat diperlukan untuk penghidupan masyarakat demi kebaikan dan ketentraman bersama.

UU Pengelolaan Keuangan Haji di dalam konsiderannya menyebutkan bahwa telah terjadi peningkatan jumlah jamaah haji tunggu sehingga mengakibatkan terjadinya penumpukan akumulasi dana haji. Sehingga nominal dana haji terus meningkat maka

${ }^{22}$ Sudikno Mertokusumo, (2002), Mengenal Hukum Suatu Pengantar, Yogyakarta: Liberty, hlm. 71

${ }^{23}$ Satjipto Raharjo, (2005), Hukum dan Masyarakat, Bandung: Angkasa, hlm. 65.

${ }^{24}$ Purnadi Purbacaraka dan Soerjono Soekanto, (2010), Perihal Kaidah Hukum, Bandung: Alumni, hlm. 58. 
diperlukan pengelola keuangan haji yang efektif, efisien, transparan, akuntabel berdasarkan ketentuan perundang-undangan.

Sehingga tujuan dari UU Pengelolaan Keuangan Haji adalah menghadirkan pengaturan yang bertujuan untuk mengamankan dan menertibkan dana haji masyarakat. Terkait isu penggunaan dana haji untuk investasi infrastruktur, BPKH harus mempertimbangkan asas pengelolaan Keuangan Haji yaitu: prinsip syariah, prinsip kehatihatian, manfaat, nirlaba, transparan dan akuntabel. ${ }^{25}$

Investasi syariah pada praktiknya menggunakan bentuk akad yang beragam yaitu:

1. Akad Musyarakah atau akad kerjasama antar dua pihak atau lebih dalam suatu usaha tertentu dengan penyertaan modal tertentu dengan kesepakatan-kesepakatan tertentu.

2. Akad Mudharabah adalah kerjasama antar dua orang atau lebih dan pemilik modal mempercayakan modalnya pada pengelola (mudharib) dengan kesepakatan pembagian keuntungan. Komposisinya adalah dana $100 \%$ dari pemilik modal (shahibulmal) dan keahlian dari pengelolanya (mudharib).

3. Akad Ijarah atau akad sewa yaitu akad yang memindahkan hak guna atau manfaat objek ijarah dalam waktu tertentu tanpa diikuti oleh pemindahan kepemilikan.

4. Akad kafalah adalah perjanjian antarpihak penjamin dan pihak yang dijamin (orang yang berutang) untuk menjamin kewajiban pihak yang dijamin kepada pihak lain (pihak yang berpiutang)

5. Akad Wakalah perjanjian pihak pemberi kuasa dan penerima kuasa untuk melakukan tindakan tertentu.

Beragam akad investasi syariah ini salah satunya dapat digunakan untuk investasi pembangunan investasi infrastruktur. Akad ini juga mencerminkan bahwa islam juga memberikan ruang yang halal dalam memanfaatkan harta agar bisa lebih produktif. Sebab tujuan investasi dalam Islam adalah penyebaran harta kepada seluruh masyarakat, sehingga kemanfaatan harta dapat dimanfaatkan oleh lebih banyak pihak. Akan tetapi walaupun tujuan dari investasi adalah sebuah keuntungan, namun risiko merugi tetap ada.

Pada investasi infrastruktur para pihak dapat menggunakan akad mudharabah di mana para pihak akan mendapatkan keuntungan dengan porsi yang jelas tercantum di dalam surat perjanjian. Pada akad ini pengelola investasi dana haji memanfaatkan dana yang sumbernya $100 \%$ (seratus persen) dan BPKH. BPKH harus meneliti dengan cermat investor yang akan diamanahi dana haji, hanya investor yang sudah terbukti mampu mengelola dana yang terpilih untuk selanjutnya diberikan dana haji. Akad lainnya yang berhubungan dengan investasi dana

\footnotetext{
${ }^{25}$ Lihat Pasal 2 Undang-Undang Nomor 34 Tahun 2014 tentang Pengelolaan Keuangan Haji.
} 
haji adalah akad wakalah, pada akad ini masyarakat memberikan kuasa kepada investor dengan diwakili oleh BPKH.

Pada investasi infrastruktur para pihak dapat menggunakan akad mudharabah di mana para pihak akan mendapatkan keuntungan dengan porsi yang jelas tercantum di dalam surat perjanjian. Pada akad ini pengelola investasi dana haji memanfaatkan dana yang sumbernya $100 \%$ (seratus persen) dan BPKH. BPKH harus meneliti dengan cermat investor yang akan diamanahi dana haji, hanya investor yang sudah terbukti mampu mengelola dana yang terpilih untuk selanjutnya diberikan dana haji. Akad lainnya yang berhubungan dengan investasi dana haji adalah akad wakalah, pada akad ini masyarakat memberikan kuasa kepada investor dengan diwakili oleh BPKH.

Saat ini penggunaan dana haji untuk infrastruktur masih sebagai wacana, namun ketika wacana ini direalisasikan maka dalam hal risiko untung dan rugi dalam investasi harus menjadi pertimbangan yang matang oleh BPKH. Apabila memang terjadi kondisi merugi maka sudah seharusnya BPKH bertanggungjawab secara penuh mengingat dana yang digunakan milik masyarakat yang hendak melaksanakan ibadah haji. BPKH harus tetap memprioritaskan pemberangkatan haji dan tetap memberikan fasilitas pelayanan yang maksimal agar jamaah haji dapat melaksanakan ibadah dengan khusyu.

UU Pengelolaan keuangan haji memberikan wewenang kepada BPKH untuk mengelola dana haji yang terkumpul. Oleh BPKH menurut UU Pengelolaan Keuangan Haji BPKH berwenang mengelola dana haji dalam sektor investasi berupa produk perbankan, surat berharga, emas, investasi langsung dan investasi lainnya, pelaksanaannya sesuai dengan prinsip syariah dengan mempertimbangkan aspek keamanan, kehati-hatian, nilai manfaat dan likuiditas.

BPKH dikategorikan dalam bentuk badan hukum publik yang semi otonom yang mana institusinya bersifat independen. Terbentuk karena adanya undang-undang dan akhirnya melahirkan hak dan kewajiban konstitusioanal untuk melaksanakan program negara terkait dengan pengelolaan dana haji. BPKH terdiri dari badan pelaksana dan dewan pengawas.

Terkait dengan investasi infrastruktur jika dilaksanakan sesuai dengan rambu-rambu yang ada di dalam undang-undang ini tentunya mungkin terjadi. Ketika investasi sudah direalisasikan namun keadaan buruk yang tidak diinginkan terjadi, maka BPKH sebagai pengelola keuangan haji harus mempersiapkan langkah pertanggungjawaban agar masyarakat tidak khawatir kehilangan dananya. 
Jika terjadi kerugian akibat kegagalan investasi maka berdasarkan Pasal 53 Ayat (1) UU Pengelolaan Keuangan Haji menyakatakan bahwa "anggota badan pelaksana dan anggota dewan pengawas bertanggung jawab secara tanggung renteng terhadap kerugian atas penempatan dan/atau investasi Keuangan Haji secara keseluruhan yang ditimbulkan atas kesalahan dan/atau kelalaian dalam pengelolaannya."

Untuk menjaga dana umat Islam agar lebih aman lagi seharusnya pertanggungjawaban dana ini tidak hanya sebatas tanggung renteng saja, harusnya ditambah dengan pertanggungjawaban secara privat, yang mana jika kerugian terjadi karena kesalahan BPKH maka pertanggungjawabannya harus melibatkan harta pribadi mereka untuk mempertanggungjawabakan kerugian tersebut.

Tujuan pertanggungjawaban privat adalah agar BPKH benar-benar menerapkan prinsip kehati-hatian dalam menginvestasikan dana haji masyarakat. Selain itu keamanan investasi menjadi prioritas utama dibandingkan dengan bagi hasil yang dijanjikan.

Pertanggungjawaban kedua dari investasi infrastruktur adalah pengelolaan bagi hasil yang didapat oleh BPKH jika investasi berlangsung dengan aman. Sesuai dengan keinginan Presiden Joko Widodo yang beliau sampaikan pada saat pelantikan BPKH yaitu keuntungan investasi digunakan untuk meringankan biaya setoran akhir haji dan pelayanan jamaah haji lebih baik lagi.

Nisbah pembagian hasil harus ditentukan terlebih dahulu sebelum akad disepakati oleh para pihak. Harus dibuat regulasinya minimal dalam bentuk perjanjian tertulis. Bagi hasil yang ini juga tidak boleh bertentangan dengan prinsip syariah.

Bagi hasil merupakan ciri khas dari investasi syariah. Investasi berstandar prinsip syariah pembagian hasil usaha ditetapkan di awal akad. Besarnya persentasi para pihak ditentukan dengan kesepakatan bersama dengan kerelaan para pihak (an-tarodin min kum) tanpa adanya paksaan. Adapun teknis pembagian hasil yang biasa dipraktikkan oleh pihak perbankan syariah adalah: profit sharing dan revenue sharing.

Adapun yang dimaksud dengan profit sharing adalah perhitungan bagi hasil berdasarkan kepada hasil bersih dari total pendapatan setelah dikurangi dengan biaya-biaya yang dikeluarkan untuk memperolah pendapatan tersebut. Profit sharing akan selalu disandingkan dengan loss sharing yang diartikan pembagian untung dan rugi dari pendapatan yang diterima atas hasil usaha yang dilakukan. ${ }^{26}$

${ }^{26}$ Suherman, (2017)“Penetapan Prinsip Bagi Hasil Pada Perbankan Syariah Sebuah Pendekatan AlMaqhasidu Al-Syariah”, Al-Mashlahah Jurnal Hukum dan Pranata Sosial Islam, Volume 2 Nomor 03, hlm. 296. 
Profit sharing and loss sharing pada praktiknya digunakan untuk investasi usaha yang mana bentuk kerjasamanya menggunakan akad mudharabah yaitu perjanjian kerjasama antara pemodal (investor) dan pengelola modal (enterpreneur), kedua belah pihak menjalankan kegiatan investasi yang mana para pihak terikat dengan perjanjian kerjasama. Perjanjian ini mengandung unsur pembagian keuntungan dan pembagian kerugian berdasarkan persentasi yang mereka sepakati. Sehingga dalam kegiatan investasi ini kerugian bagi pemodal tidak mendapatkan kembali modal investasinya secara utuh ataupun hilang secara keseluruhan, sedangkan pengelola modal investasi tidak mendapatkan upah kerja yang selama ini dia kelola.

Sedangkan sistem yang kedua revenue sharing adalah sistem bagi hasil yang dihitung dari total pendapatan pengelolaan dana tanpa dikurangi dengan biaya pengelolaan dana. Jadi hakikatnya yang dimaksud dengan revenue sharing perhitungan bagi hasil atas dasar total seluruh pendapatan yang diterima sebelum dikurangi biaya-biaya yang telah dikeluarkan untuk memperoleh pendapatan tersebut. ${ }^{27}$ Revenue sharing lebih dikenal dengan perhitungan pendapatan kotor. Biaya pihak perbankan menggunakan teknis pembagian ini pada produk pendanaan perbankan syariah.

Dalam hal pertanggungjawaban pengelolaan dana haji diperlukan regulasi hukum yang lebih khusus misalnya saja dengan perubahan pada Undang-Undang atau Peraturan Pemerintahnya dengan penambahan Pasal pengelolaan keuntungan investasi untuk memperbaiki pelayanan haji atau untuk menurunkan biaya haji. Jika kegiatan investasi merugi BPKH mampu mempertanggungjawabkan secara privat agar investasi ini dilakukan benarbenar dengan prinsip syariah, prinsip kehati-hatian dan prinsip keamanan.

\section{PENUTUP}

\section{Kesimpulan}

Berdasarkan pembahasan di atas maka disimpulkan bahwa:

1. Penggunaan dana haji untuk investasi inftastruktur tidak bertentangan dengan ketentuan hukum yang berlaku, selama investasi ini dilakukan dengan berstandar prinsip syariah dengan standar tidak ada unsur: maisir, gharar, riba, batil, Bay'i ma'dum dan ihtikar.

2. BPKH harus benar-benar bertanggungjawab dengan dana haji tersebut. Jika investasi menguntungkan maka pembagian hasilnya benar-benar untuk meningkatkan kualitas

\footnotetext{
${ }^{27}$ Ibid.
} 
pelayanan haji dan juga menekan biaya haji tersebut. Namun jika investasi merugi BPKH juga harus bertanggungjawab tidak hanya tanggung jawab renteng namun harus ditambah dengan tanggung jawab secara privat, hal ini bertujuan agar kegiatan investasi benarbenar dilakukan dengan hati-hati dan menghindari adanya korupsi oleh anggota badan tersebut. Sehingga dalam hal ini perlu penambahan pengaturan baru terkait dengan tanggung jawab BPKH dalam pengelolaan dana haji untuk investasi.

\section{Saran}

Dana haji yang hendak diinvestasikan hendaklah digunakan dengan sangat hati-hati. Keuntungan yang akan didapatkan pada unsur usaha investasi ini sebaiknya digunakan untuk memperbaiki pelayanan haji jamaah Indonesia dari penginapan, katering makanan dan juga alat transportasi yang digunakan untuk membawa jamaah haji. Pengelolaan investasi dana haji juga harus tunduk dengan prinsip-prinsip syariah dalam berinvestasi agar hasil keuntungan investasi yang didapat benar-benar diyakini oleh jamaah terkait dengan kehalalannya. 


\section{DAFTAR PUSTAKA}

\section{Buku}

Abdul Kadir Muhammad, (2004), Hukum dan Penelitian, Bandung: PT. Citra Adtya Bakti,.

Ahmad Azhar Basyir, (2000), Asas-Asas Hukum Muamalah, Yogyakarta: UII Press.

Abdul Aziz, (2010), Manajemen Investasi Syariah, Bandung: Alfabeta.

Nurul Huda dan Mustofa E. Nasution, (2008), Investasi Pada Pasar Modal Syariah Jakarta: Kencana.

Purnadi Purbacaraka dan Soerjono Soekanto, (2010), Perihal Kaidah Hukum, Bandung: Alumni.

Suad Hasan, (2005), Dasar-dasar Teori Potofolio Dan Analisis Sekuritas, Yogyakarta: UPP AMP YKPN.

Sudikno Mertokusumo, (2002), Mengenal Hukum Suatu Pengantar, Yogyakarta: Liberty.

Satjipto Raharjo, Hukum dan Masyarakat, Bandung: Angkasa.

\section{Peraturan Perundang-Undangan}

Undang-Undang Nomor 13 Tahun 2008 tentang Penyelenggaraan Ibadah Haji.

Undang-Undang Nomor 34 Tahun 2014 Tahun 2014 tentang Pengelolaan Keuangan Haji.

Peratutan Pemerintah Nomor 5 Tahun 2018 tentang Pelaksanaan Undang-Undang Nomor 34 Tahun 2014 tentang Pengelolaan Keuangan Haji.

Kompilasi Hukum Ekonomi Syariah.

Fatwa DSN-MUI No.80/DSNMUI/III/2011 tentang Penerapan Prinsip Syariah dalam Mekanisme Perdagangan Efek Bersifat Ekuitas Di Pasar Reguler Bursa Efek.

\section{Jurnal}

Abdur Rahman Adi Saputera dan Muhammad Yusuf Putra, (2020), “Tinjauan Hukum Islam Terhadap Problematika Investasi Haji Pada Masa Pandemi Virus Covid-19”, El Ahli: Jurnal Hukum Keluarga Islam, Volume 1 Nomor 2, Desember 2020.

Ahmad Fathurrozi, (2019), “Analisis Maslahah Mursalah Terhadap Pengelolaan Dana Haji Oleh BPKH Untuk Investasi Pembangunan Infrastrktur", Skripsi Universitas Islam Negeri Sunan Ampel Fakultas Syariah, Surabaya.

Elif Pardiansyah, (2017), "Investasi dalam Perspektif Ekonomi Islam: Pendekatan Teritis dan Empiris”, Economica: Jurnal Ekonomi Islam, Volume 8 Nomor 2 Tahun 2017. 
Habibah Yahya, Mohd Suhaini Abdul Majid, Aida Zuraina Mir Ahmad Talaat, Mohd Zaid Zulkifli, dan Nor Shaiza Mir Ahmad Talaat, (2016), "Tabungan Haji Malaysia as a World Role Model of Islamic Management Instituions", Internasional Journal of Bussines and Management Invention, Volume 5 Nomor 11 Tahun 2016.

Ina Nur Inayah, (2020), "Prinsip-Prinsip Ekonomi Islam dalam Investasi Syariah”, Jurnal Ilmu Akuntansi dan Bisnis Syariah, Volume II Nomor 02, Juli 2020.

Maria Ulfa Kn, (2019), "Pengelolaan Dana Haji Oleh Badan Pengelola Keuangam Haji Tanpa Pengawasan Otoritas Jasa Keuangan (Perspektif Hukum Islam)", Tesis Universitas Islam Negeri Sunan Kalijaga, Magister Ilmu Syariah.

Rony Wahyu Hidayat, (2014), "Peluang Dan Tantangan Investasi Properti Di Indonesia", Jurnal Akuntansi AKUNESA 2, Nomor 2.

Sulasi Rongiyati, (2017), "Perspektif Yuridis Pengelolaan Dana Haji Untuk Investasi Infrastrktur", Majalah Info Singkat Hukum, Volume IX Nomor 15/I/Puslit/Agustus/2017.

Suherman, (2017)“Penetapan Prinsip Bagi Hasil Pada Perbankan Syariah Sebuah Pendekatan Al-Maqhasidu Al-Syariah", Al-Mashlahah Jurnal Hukum dan Pranata Sosial Islam, Volume 2 Nomor 03.

\section{Internet}

Beritagar, $\quad$ https://beritagar.id/artikel/berita/pro-konta-dana-haji-untuk-pembiayaaninfrastruktur.

Nasional Kompas, https://nasional.kompas.com/red2017/07/30/13415151/jokowi-investasidana-haji-harus-mengentungkan.

Republika, https://www.republika.co.id/berita/koran/opini-koran/14/06/20/n7gb8840pengelolaan-dana-haji.

Liputan6.com, https://liputan6.com "Jubir Wapres Sampaikan Klarifikasi Video Ma'ruf Amin tentang Investasi Dana Haji." 